\title{
Cecal lymphoma in a male Rottweiler dog
}

\author{
A.E.Ashour ${ }^{1}$, E.A.Berbish ${ }^{1}$, A.Osman ${ }^{2} \&$ M.M.Shokry ${ }^{*}$ \\ ${ }^{1}$ Department of Surgery, Anesthesiology \& Radiology, Cairo University, Giza, Egypt. \\ ${ }^{2}$ Department of Pathology, Faculty of Veterinary Medicine, Cairo University, Giza, Egypt.
}

*Corresponding author: M.M.Shokry, Department of Surgery, Anesthesiology \& Radiology, Cairo University, Giza, Egypt.

Received date: May 08, 2020; Accepted date: July 21, 2021; Published date: July 24, 2021

Citation: A E Ashour, E A Berbish, A Osman \& M M Shokry. (2021) Cecal lymphoma in a male Rottweiler dog. International Journal of Clinical Case Reports and Reviews. 7(5); DOI: 10.31579/2690-4861/134

Copyright: (c) 2021 M.M.Shokry, This is an open-access article distributed under the terms of the Creative Commons Attribution License, which permits unrestricted use, distribution, and reproduction in any medium, provided the original author and source are credited.

\begin{abstract}
A 6-year-old male Rottweiler dog presented with a marked weight loss combined with abdominal pain and diarrhea over 3 month. Hematology revealed lymphocytosis, neutrophilia and eosinophilia. Abdominal ultrasound revealed a heteroechoic mid-abdominal mass with a focal hypoechoic area measuring $6.0 \times 5.0$ $\mathrm{cm}$ but with a confusing origin. The mass was resected and intestinal anastomosis was performed after celiotomy. Histopathology of the mass demonstrated massive lympho-proliferative lesions were diagnosed as low grade lymphoma with diffuse small lymphocytic (DSL-plasmacytoid) pattern. The dog was recovered and a one-month ultra sonography follow-up showed no-recurrence.
\end{abstract}

Key words: lymphoma; cecal diverticulum; weight loss; diarrhea

\section{Introduction}

GI mesenchymal tumors are mainly comprised of a series of spindle cell tumors, including GI stromal tumors, leiomyomas, lymphomas, schwannomas, inflammatory fibroid polyps, fibromatoses and leiomyosarcomas (Greenlee et al., 1990; Teske et al., 1994; Davis et al, 2000; Miettinen and Lasota, 2001). Changes in classifications of GI tumors have emerged due to recent advances in immunohistochemistry and electron microscopy since GI stromal tumors in about $95 \%$ of cases stain positively for the protein CD117 (Day et al, 2003; Giuly et al.,2003). Differing between benign and malignant GISTs may develop few problems however, GISTs may appear benign both in mitoticcounts and lack of cellular atypia, but still behave malignantly (Miettinen et al, 2002). GISTs smaller than $3 \mathrm{~cm}$ are generally considered benign tumors (Bonsaing et al., 2007) and GISTs larger than 3-5 cm, with mitotic counts greater than $2 / 10$ high power field or that involved more layers are generally considered high-risk tumors for malignancy ( Giuly et al, 2003; Miettinen et al, 2000). The presented case is reported due to its rare occurrence.

\section{Case description}

A $45 \mathrm{~kg}$, 6-year male Rottweiler was attended at the surgery clinic of the faculty of Veterinary Medicine,Cairo University, with a history of anorexia, lethargy, cachexia, weight loss, abdominal pain and diarrhea( over 3 month period). Vomiting and seizures were not reported. Vaccinations were up to date and housed mainly indoors, with some time spent out.

\section{Clinical examination}

At physical examination, the dog was alert with normal temperature, pulse and respiration, pale $\mathrm{mm}$, and palpation of the abdomen and lymph nodes were normal. Blood sample was collected for complete blood count (CBC), serum biochemical analysis for liver and kidney functions, serum amylase and lipase values for pancreatic lesions and blood parasites. An abdominal ultrasound and thoracic radiographs were performed for any pathological lesions. 




Figure 1: Ultrasonographic image of the intestinal mass located at the ileo-cecal junction. Note the overall thickened and disruption wall.

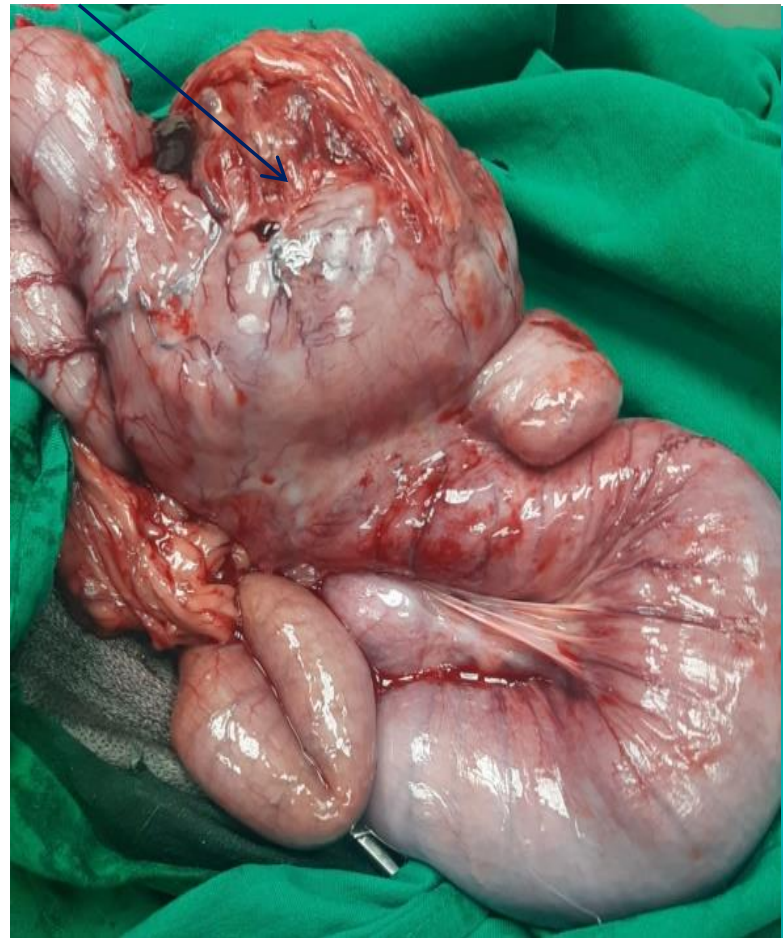

A

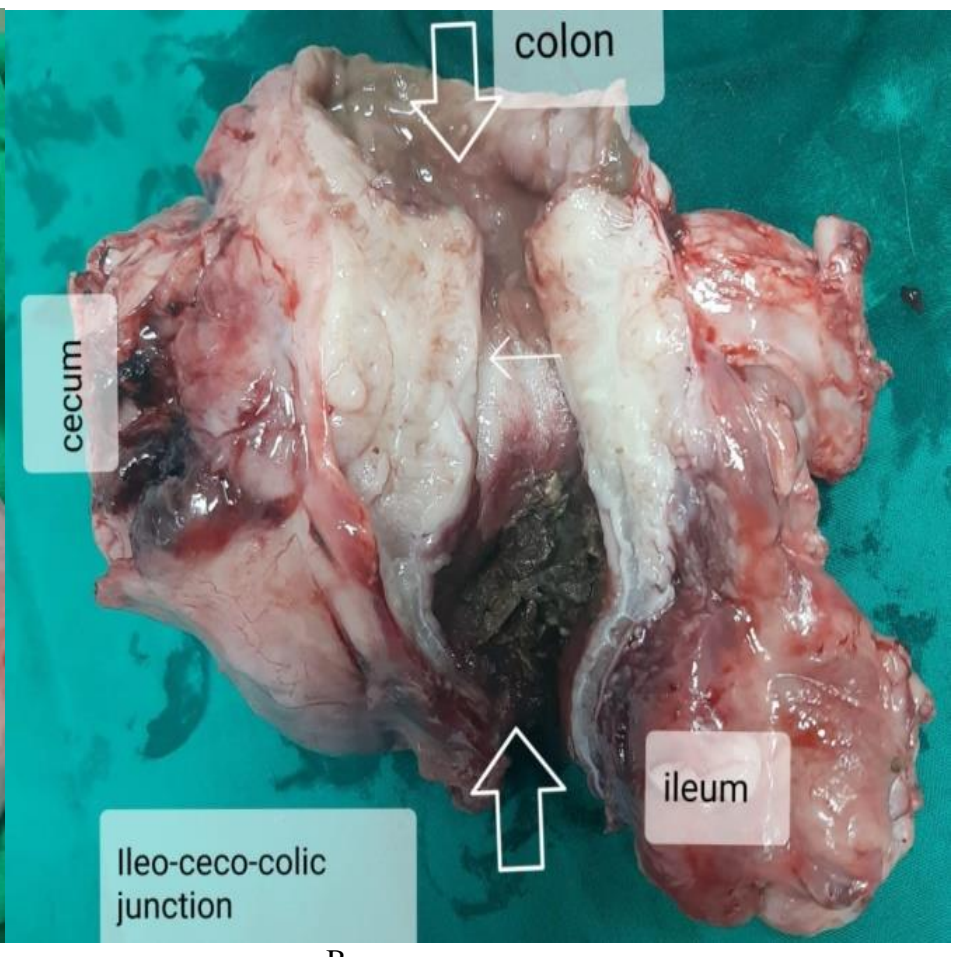

B

Figure 2: (A) The involved segment of the intestine including the mass (arrow) exteriorized after laparotomy.

(B) Cut surface of the enucleated mass, showing a fibrin coated mucosa and hemorrhagic adjacent mucosa. 


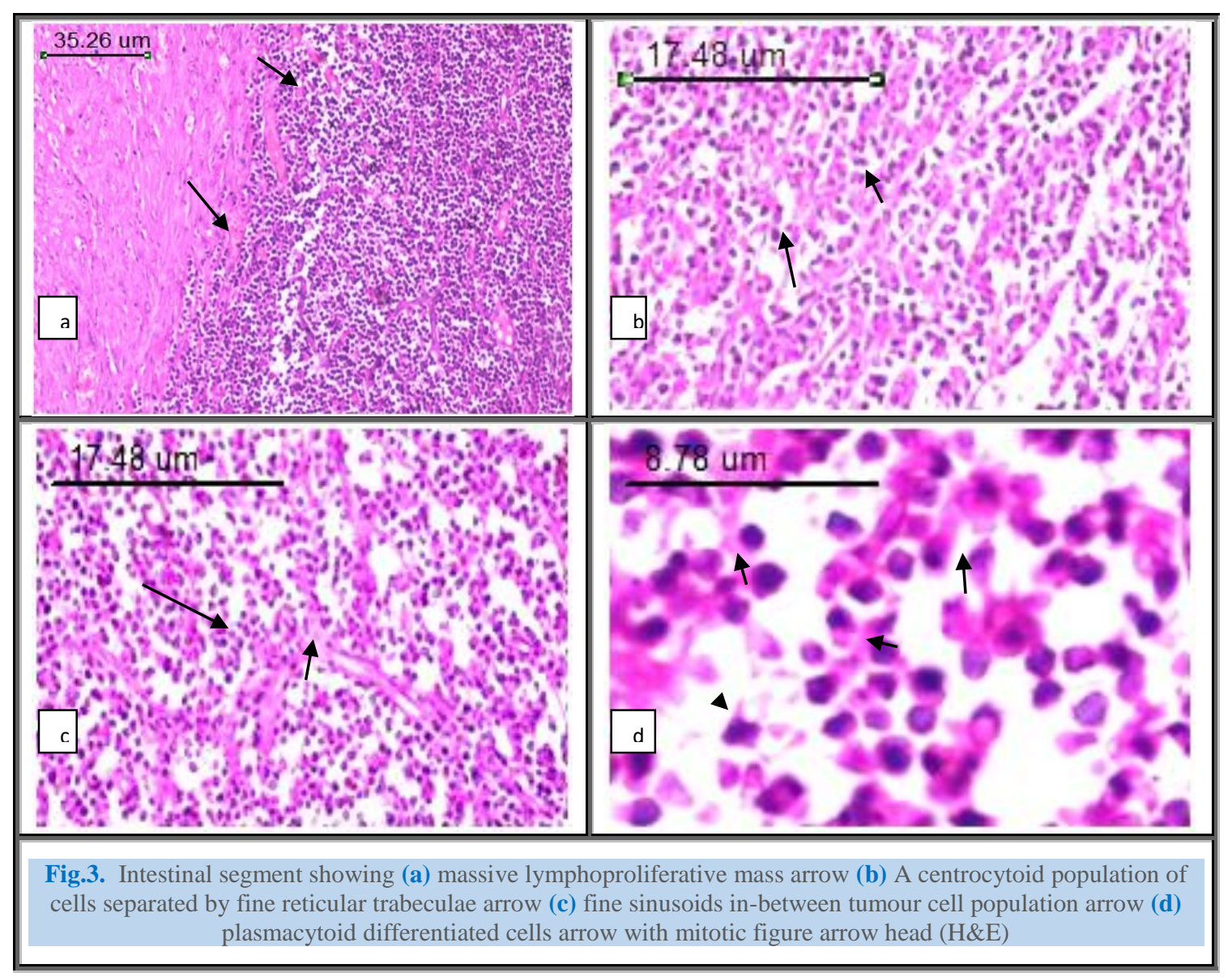

\section{Results}

CBC showed moderate leukocytosis with absolute neutrophilia (41.80\%), lymphocytosis $(41.40 \%)$, monocytosis $(10.60 \%)$ and eosinophilia (4.08\%). Serum biochemical analysis was within the normal range. Examination for blood parasites was negative. Thoracic radiology showed no pathology. Abdominal ultrasonography detected a heteroechoic midabdominal mass with a focal hypoechoic area measuring $6.0 \times 5.0 \mathrm{~cm}$ but with confusing origin (fig.1).The remainder of the intestinal tract and viscera were unremarkable. Neither lymph adenopathy nor free fluid were noted. Surgical abdominal exploration under general anesthesia revealed an invasive mass at the ileo-cecal junction. The mass including the involved part of the intestine was resected with subsequent intestinal anastomosis. The abdomen was lavaged with sterile saline solution. The anastomosis site was omentalised and the abdominal wall was closed routinely. The enucleated mass including the resected intestinal part was fixed in $10 \%$ formol saline and submitted for histopathology (Fig.2 A $\& B)$.The dog postoperative recovery was uneventful and kept under supportive and antibiotic therapy for one week. Clinical and ultrasonography follow-up one month later showed no evidence of mass reccurence.

\section{Histopathological examination}

Tissue specimens from tumor mass and intestinal segment were fixed in $10 \%$ neutral buffered formalin. The fixed specimens were then trimmed, washed and dehydrated in ascending grades of alcohol, cleared in xylene, embedded in paraffin, sectioned at 4-6U thickness and stained by hematoxylin and eosin were used (Bancroft et al.,2013).
Massive lymphoproliferative lesions were diagnosed as low grade lymphoma with diffuse small lymphocytic (DSL-plasmacytoid) pattern. The histological section dominated a monotonous morphology of the tumour cell population, mainly composed of uniform small oval tumour cells. The tumour mass was closely attached to external muscular layer of the intestinal wall forming bulky nodular formation containing uniform, small-sized cells. The architecture is diffuse, the mitotic index is low and mitoses may not be observed. The nuclei appeared the same size as a canine erythrocyte and uniformly round. The chromatin pattern was coarsely aggregated. Nucleoli were absent or there may be one small, usually central nucleolus. The cytoplasm was usually scant and poorly staining. In this case histological sections demonstrated a diffuse homogeneous population of small cells with low mitotic rate and plasmacytoid differentiated cells. A centrocytoid population of cells with eccentrically localized basophilic nucleus and adjacent layer of lighter cytoplasm resembling to plasma cells. The stroma consisted of fine sinusoids, or fine reticular networks with unique, visible trabeculae (Fig. 3).

\section{Discussion}

According to clinicohistopathological data,the definitive diagnosis of the presented case is low grade lymphoma with small lymphocytic pattern. With respect to the patient's presented reported signs, there were crampy abdominal pain associated with anorexia, bloating, diarrhea and weight loss. Almost similar signs have been reported in dogs with stromal intestinal tumors (Frgelecova et al, 2013; Maia et al., 2009; Greenlee et al., 1990; Greenlee 1988). Although most dogs with lymphoma are characterized by the presence of non-painful periphera lymphadenopathy 
(Greenlee et al., 1990), the present case showed normal peripheral lymph nodes. Hematology revealed neutrophilia, lymphocytosis, monocytosis and eosinophilia which indicate intense inflammatory response.

The histological grades of canine lymphomas were classified as low (small lymphocytic or centrocytic lymphomas) or intermediate to high (diffuse large cell, centroblastic, and immunoblastic lymphomas) (Greenlee et al., 1990). Clinical staging is an important factor in predicting survival and response to treatment in man (Lieberman et al., 1986). The present case was diagnosed as low grade lymphoma which is rarely noticed in dogs and usually goes unrecognized by most owners with improved survival rate while almost all dogs may have advanced grades (intermediate or high) (Madewell 1975). Treatment was by surgical exicision of the lesion and intestinal anastomosis without chemotherapy since ultrasonographic examination follow-up for one month indicated no recurrence.

\section{References}

1. Bancroft J D, A Stevans \& D R Turner. (2013) Theory and practice of histological techniques. 4th Ed. Churchill Livingstone, Edinburgh, London, Melbourne, New York.

2. Day D, J Jass, A B Price, NA Shepherd et al. (2003) In Morson \& Dawson's Gastrointestinal pathology. Massachusetts: Blackwell Science Ltd. 205-209, 383-388.

3. Davis G B, D K Blanchard, G.F.Hatch et al. (2000) Tumors of the stomach. World J. Surg. 24,412-420.

4. Frgelecova L, M.Skoric, P. Fictum \&R. Husnik. (2013) Canine gastrointestinal tract tumours: a retrospective study of 74 cases. Acta Vet Brno. 82, 387-392.

5. Giuly J A, R Picand, D.Giuly et al. (2003) Von Recklinghausen disease and gastrointestinal stromal tumors. Am J Surg.185; 8687.
6. Greenlee P G, D A Filippa, F W Quimby FW et al. (1990) Lymphoma in dogs: a morphologic, immunologic, and clinical study, Cancer. 66; 480-490.

7. Greenlee P G. (1988) Morphologic and immunologic characterization and response to therapy of canine lymphoma (thesis). Cornell University Graduate college of Medical Sciences.

8. Lieberman P.H, D.A.Filippa, H.T.Thaler et al. (1986) Evaluation of malignant lymphoma using three classifications and the working formulation: Four hundred eighty-two cases with medical follow-up of 11.9 years. Am J Med. 81; 365-380.

9. Madewell B.R. (1975) Chemotherapy for canine lymphoma. Am J Vet Res. 36; 1525-1528.

10. Maia C A A, A Avila, J R F Cesar et al. (2009) Intestinal leiomyosarcoma associated with hypoglycemia in a Dog-Case Report. World small anima veterinary association. World congress proceedings.

11. Miettinen M, W El-Rifai, H.L.Sobin et al. (2002) Evaluation of malignancy and prognosis of gastrointestinal stromal tumors: a review. Human Pathol. 33; 478-483.

12. Miettinen M, Lasota J. (2001) Gastrointestinal stromal tumorsdefinition, clinical, histological, immunohistochemical, and molecular genetic features and differential diagnosis. Virchows Arch. 438; 1-12.

13. Miettinen M., J.Y.Blay,L.H. Sobin et al,. 2000. World health organization classification of tumors. Pathology and genetics of tumors of the digestive system, Lypn: IARC Press pp. 29; $142-$ 143.

14. Teske E, P Van Heerde, G.R.Rutteman et al. (1994) Prognostic factors for treatment of malignant lymphoma in dogs. J Am Vet Med Assoc. 205; 1722-1728.

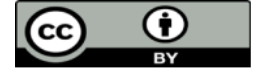

This work is licensed under Creative Commons Attribution 4.0 License

To Submit Your Article Click Here: Submit Manuscript

DOI: $10.31579 / 2690-4861 / 134$
Ready to submit your research? Choose Auctores and benefit from:

* fast, convenient online submission

* rigorous peer review by experienced research in your field

* rapid publication on acceptance

* authors retain copyrights

* unique DOI for all articles

* immediate, unrestricted online access

At Auctores, research is always in progress.

Learn more www.auctoresonline.org/journals/international-journal-ofclinical-case-reports-and-reviews 